\title{
A review of Fasciolopsis buski distribution and control in Indonesia
}

\author{
Muhammad Rasyid Ridha1 ${ }^{(\mathbb{D}}$, Liestiana Indriyati ${ }^{1}$ (D), Dicky Andiarsa1 ${ }^{(\mathbb{D}}$ and April Hari Wardhana ${ }^{2,3}$ (D)
}

1. Tanah Bumbu Unit for Health Research and Development, National Institute of Health Research and Development, Tanah Bumbu, South Kalimantan 72171, Indonesia; 2. Indonesian Research Center for Veterinary Science, Indonesian Agency for Agricultural Research and Development, Ministry of Agriculture Republic Indonesia, Bogor 16114, Indonesia;

3. Department of Parasitology, Faculty of Veterinary Medicine, Airlangga University, Surabaya, 60115, Indonesia.

Corresponding author: Muhammad Rasyid Ridha, e-mail ridho.litbang@gmail.com

Co-authors: LI: lis_alla@yahoo.com, DA: andiarsa@gmail.com, AHW: wardhana24id@yahoo.com Received: 09-06-2021, Accepted: 06-09-2021, Published online: 26-10-2021

doi: www.doi.org/10.14202/vetworld.2021.2757-2763 How to cite this article: Ridha MR, Indriyati $L$, Andiarsa $D$, Wardhana AH (2021) A review of Fasciolopsis buski distribution and control in Indonesia, Veterinary World, 14(10): 2757-2763.

\begin{abstract}
Fasciolopsiasis is a parasitic infection caused by the flatworm Fasciolopsis buski. Since 1982, fasciolopsiasis has been reported in Indonesia's Hulu Sungai Utara (HSU) Regency, South Kalimantan Province. Fasciolopsiasis occurs when contaminated raw or undercooked aquatic plants are consumed. Cercariae of the parasite encyst in a variety of aquatic plants and grow into metacercariae that infect and reproduce in the human intestine. Until now, treatment for F. buski infection in the HSU Regency has been comparatively short, with patients receiving only a single dose of praziquantel, $30 \mathrm{mg} / \mathrm{kg}$ body weight, without further observation. A long-term effort through health promotion activities and intensive health education, particularly for elementary school children enrolled in the School Health Program, is ongoing to help prevent fasciolopsiasis from spreading and to improve environmental sanitation. Through 2018, intervention efforts successfully reduced the incidence of $F$. buski infection. Sustaining surveillance and investigation of fasciolopsiasis, including identification of new cases and community education, is critical for the elimination of the parasite from Indonesia. This review describes the spread of $F$. buski and its possible impact on public health to understand the critical nature of continuing F. buski surveillance and control efforts.
\end{abstract}

Keywords: fasciolopsiasis, Fasciolopsis buski, Indonesia, trematode.

\section{Introduction}

Fasciolopsiasis is an intestinal disease caused by the zoonotic trematode, Fasciolopsis buski. The disease is considered neglected though infection with $F$. buski is endemic in several countries, including South and Central China [1], Taiwan [2], Southeast Asia (Thailand, Vietnam, Malaysia, Laos, and Kamboja) [3,4], Bangladesh [5], Japan [6], and Indonesia [7]. The parasite is estimated to infect approximately 10 million people worldwide [8].

The first case of fasciolopsiasis in Indonesia was reported in 1920, though the original case remains unidentified. Information on disease incidence is also limited. A remarkable report was published in 1982 for the Hulu Sungai Utara (HSU) Regency, South Kalimantan Province (Figure-1). Sungai Papuyu and Kalumpang Dalam villages in the Babirik subdistrict, Putat Atas and Padang Bangkal villages in the Sungai Pandan subdistrict, and Sarang Burung and Telaga Mas villages in the Danau Panggang subdistrict were identified as endemic areas for fasciolopsiasis. The incidence of infection was $27 \%$, and 148 positive cases out of 548 people were examined. The highest incidence occurred

Copyright: Ridha, et al. Open Access. This article is distributed under the terms of the Creative Commons Attribution 4.0 International License (http://creativecommons.org/licenses/by/4.0/), which permits unrestricted use, distribution, and reproduction in any medium, provided you give appropriate credit to the original author(s) and the source, provide a link to the Creative Commons license, and indicate if changes were made. The Creative Commons Public Domain Dedication waiver (http://creativecommons.org/ publicdomain/zero/1.0/) applies to the data made available in this article, unless otherwise stated. among elementary school students, $79.1 \%$, who presented with severe diarrhea [7]. The National Institute of Health Research and Development examined fasciolopsiasis occurrence in the villages of Sungai Papuyu, Kalumpang Dalam, Sarang Burung, Telaga Mas, Putat Atas, Padang Bangkal, and Sapala Bararawa and found $7.8 \%$ of 1555 residents carrying the parasite [9]. Residents in Kalumpang Dalam Village showed a notably high prevalence of infection (Table-1) [9-17]. This village has been a high prevalence area in the HSU for many years. HSU conducted the last survey in 2018; the survey was not repeated the following year due to the absence of cases. However, worm control was never resumed for animals that serve as reservoirs for the parasite. Thus, cases could still resurface. This article focuses on the spread of F. buski and its possible impact on public health in the HSU. Stakeholders can use this information to understand the critical nature of continuing F. buski surveillance and control efforts.

This review updates $F$. buski distribution and control methods in Indonesia. We identified studies through an automatic database search of the National Library of Medicine's PubMed database and a manual search using Google Scholar. In addition, data from the South Kalimantan Provincial Health Office and the Republic of Indonesia's Ministry of Health were searched and collected for analysis.

\section{F. buski Life Cycle}

F. buski is the cause of fasciolopsiasis. The parasite is the world's largest trematode. Humans are its definitive host, and animals serve as reservoir hosts (HR). The 
worm lives and reproduces in the intestine and does not invade systemically. The life cycle of $F$. buski requires two intermediate hosts, HP I - a freshwater snail and HP II - aquatic plants (Figure-2) $[18,19]$.

Fasciolopsiasis occurs in distinct reservoir hosts in different regions. Pigs are the most common reservoir in Kwangtung Province, China [20], and Southeast India [21]. Swamp buffalo, ducks, and chickens are also suspected reservoir hosts [22]. Swamp buffalo are kept by residents in several areas of endemic fasciolopsiasis in the HSU, most notably Sapala Bararawa and Sungai Pandan villages, raising concerns that they carry the parasite. In other areas, particularly in Kalumpang Dalam Village, Alabio ducks and chickens serve as HR.

Freshwater snails, Lymnaea spp., and Indoplanorbis spp., as HP I hosts, were confirmed by polymerase chain reaction [17]. F. buski eggs develop into miracidia that infect suitable freshwater snails and

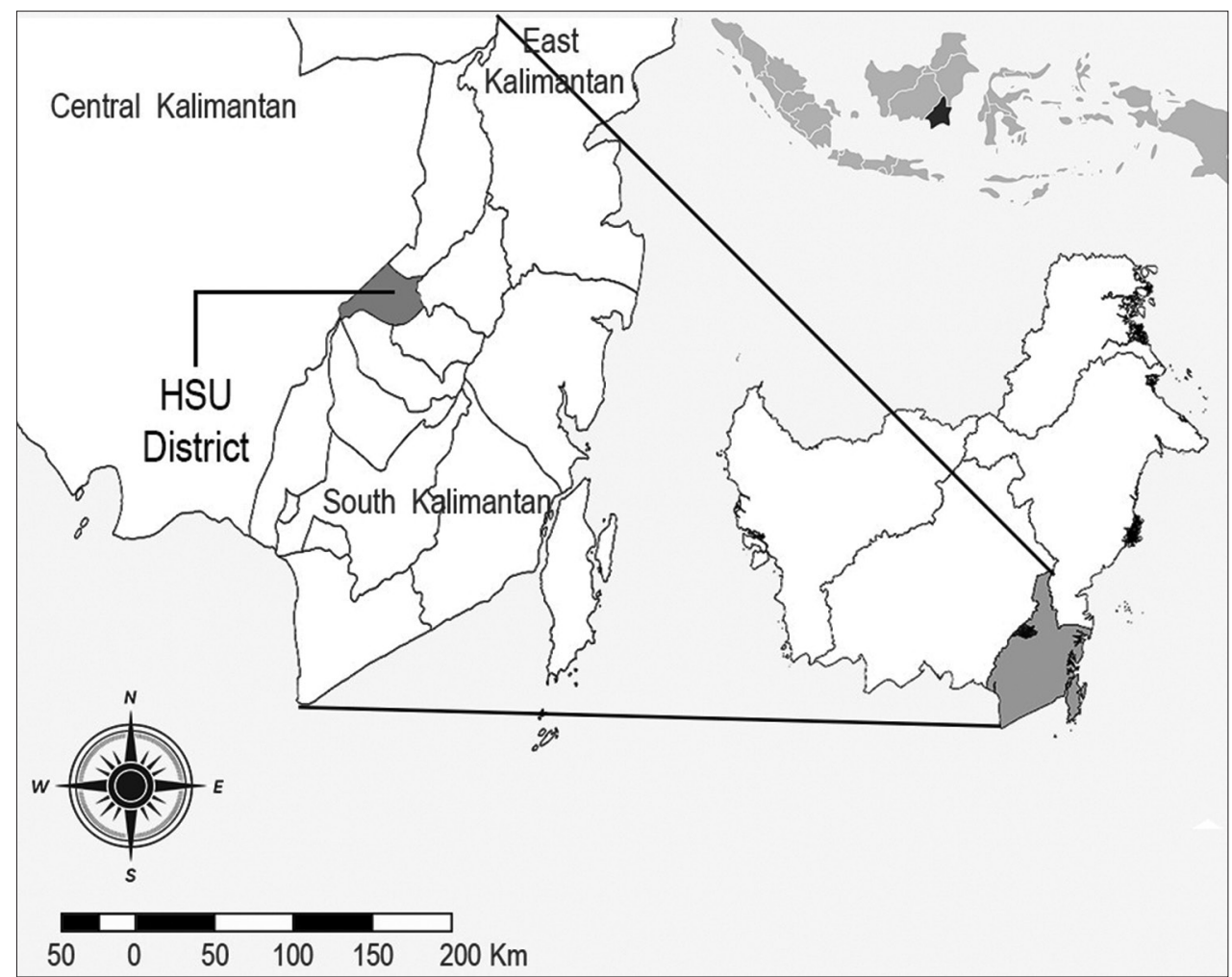

Figure-1: Endemic site of Fasciolopsis buski area in Indonesia [Source: Source: QGIS Nodebo 2.16.3].

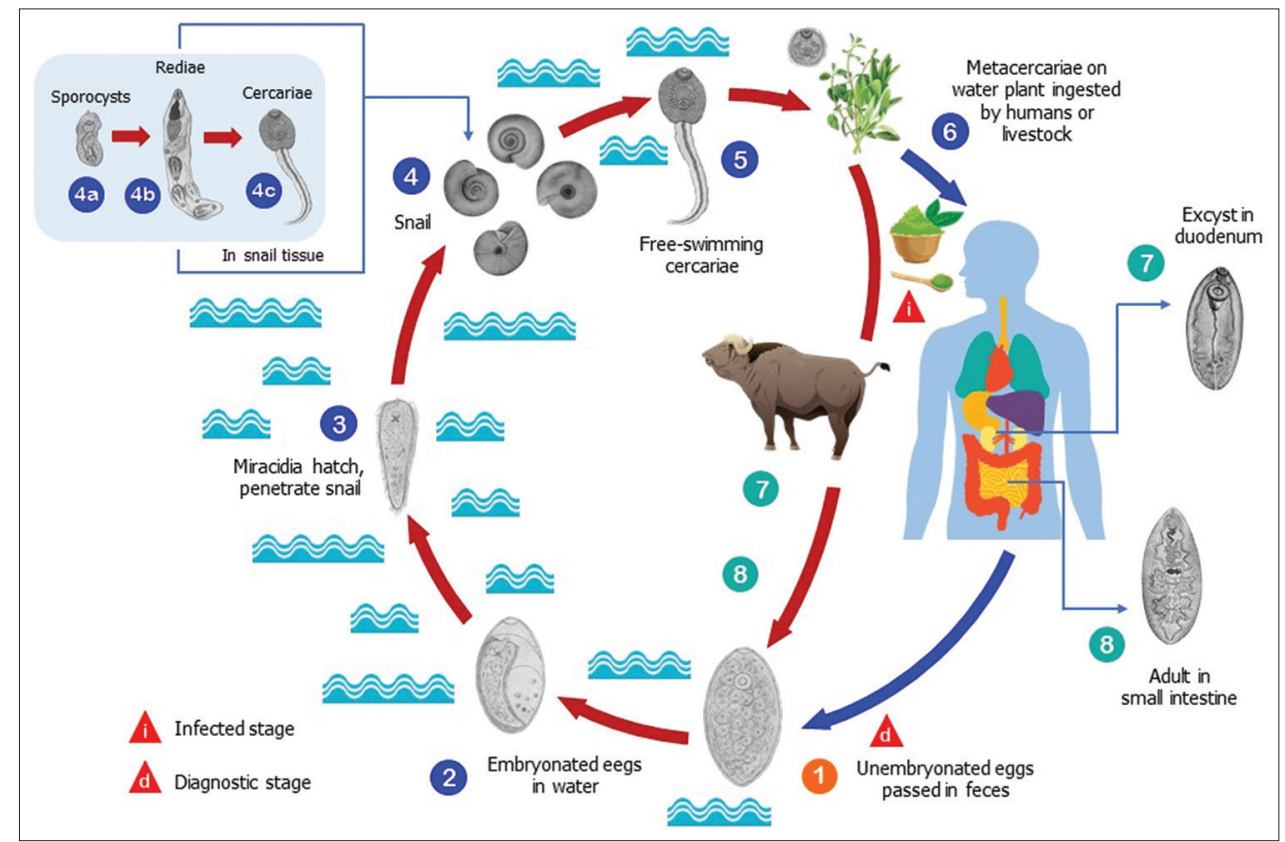

Figure-2: Life cycle of Fasciolopsis buski (modified CDC, pictures were extracted from Koan Nakagawa and freepik.com) $[18,19]$. 
Table-1: Fasciolopsiasis survey in humans and snail in Indonesia between 1985 and 2018.

\begin{tabular}{|c|c|c|c|c|}
\hline Years & $\begin{array}{l}\text { No. of } \\
\text { samples }\end{array}$ & Locations & Important findings (\%) & Reference \\
\hline \multicolumn{5}{|l|}{ Human survey } \\
\hline $1985 / 1986$ & 548 & HSU Regency & Positive 148 (27) & [9] \\
\hline $1986 / 1987$ & 2.752 & HSU Regency & Positive 504 (18.3) & [9] \\
\hline $1989 / 1990$ & 2.451 & HSU Regency & Positive 127 (5.1) & [9] \\
\hline $1990 / 1991$ & 5.943 & HSU Regency & Positive 266 (4.4) & [9] \\
\hline $1991 / 1992$ & 3.279 & HSU Regency & Positive 73 (2.2) & [9] \\
\hline 19992/1993 & 2.119 & HSU Regency & Positive 94 (4.4) & [9] \\
\hline $1993 / 1994$ & 2.204 & HSU Regency & Positive 116 (5.2) & [9] \\
\hline 1994/1995 & 2.259 & HSU Regency & Positive 167 (7.3) & [9] \\
\hline $1995 / 1996$ & 2.286 & HSU Regency & Positive 138 (6) & [9] \\
\hline $1996 / 1997$ & 2.881 & HSU Regency & Positive 105 (3.6) & [9] \\
\hline $1997 / 1998$ & 2.580 & HSU Regency & Positive $32(1.2)$ & [9] \\
\hline $1998 / 1999$ & 286 & HSU Regency & Positive 17 (5.9) & [9] \\
\hline $1999 / 2000$ & 3.838 & HSU Regency & Positive 95 (2.4) & [9] \\
\hline 2000 & 2.724 & HSU Regency & Positive $60(2.2)$ & [9] \\
\hline 2001 & 614 & HSU regency & Positive 14 (2.2) & [9] \\
\hline $2002 / 2003$ & 274 & $\begin{array}{l}\text { Putat Atas Village, Sungai Pandan } \\
\text { District, HSU Regency }\end{array}$ & Positive 16 (5.8) & {$[10]$} \\
\hline $2002 / 2003$ & 190 & $\begin{array}{l}\text { Padang Bangkal Village, Sungai } \\
\text { Pandan District, HSU Regency }\end{array}$ & Positive 18 (9.5) & {$[10]$} \\
\hline $2002 / 2003$ & 223 & $\begin{array}{l}\text { Kalumpang Dalam Village, Babirik } \\
\text { District, HSU Regency }\end{array}$ & Positive 34 (15.2) & {$[10]$} \\
\hline $2002 / 2003$ & 236 & $\begin{array}{l}\text { Sungai Papuyu Village, Babirik } \\
\text { District, HSU Regency }\end{array}$ & Positive 20 (8.5) & {$[10]$} \\
\hline $2002 / 2003$ & 371 & $\begin{array}{l}\text { Telaga Mas Village, Danau } \\
\text { Panggang District, HSU Regency }\end{array}$ & Positive 26 (7) & {$[10]$} \\
\hline $2002 / 2003$ & 226 & $\begin{array}{l}\text { Sarang Burung Village, Danau } \\
\text { Panggang District, HSU Regency }\end{array}$ & Positive 7 (3.1) & {$[10]$} \\
\hline $2002 / 2003$ & 35 & $\begin{array}{l}\text { Sapala Bararawa Village, Danau } \\
\text { Panggang District, HSU Regency }\end{array}$ & Positive (-) & {$[10]$} \\
\hline 2006 & 227 & $\begin{array}{l}\text { Kalumpang Dalam Village Babirik } \\
\text { District, HSU Regency }\end{array}$ & Positive 11 (19.1) & [11] \\
\hline $2008 / 2009$ & 161 & $\begin{array}{l}\text { Kalumpang Dalam Village, Babirik } \\
\text { District, HSU Regency }\end{array}$ & Positive 3 (2) & [12] \\
\hline 2009 & 69 & $\begin{array}{l}\text { Sungai Papuyu Village, Babirik } \\
\text { District, HSU Regency }\end{array}$ & Positive 7 (6.14) & {$[13]$} \\
\hline 2010 & 110 & Babirik District, HSU Regency & Positive 5 (4.5) & [14] \\
\hline 2012 & 396 & $\begin{array}{l}\text { Sungai Papuyu and Kalumpang } \\
\text { Dalam Villages, Babirik District, } \\
\text { HSU Regency }\end{array}$ & Positive 11 (2.78) & [15] \\
\hline 2013 & 192 & HSU Regency & Positive $1(0.525)$ & {$[15]$} \\
\hline 2018 & 55 & $\begin{array}{l}\text { Sungai Papuyu Village, Babirik } \\
\text { District, HSU Regency }\end{array}$ & Positive $1(1,8)$ & {$[16]$} \\
\hline \multicolumn{5}{|l|}{ Snail survey } \\
\hline $2012-2013$ & $\begin{array}{l}50 \\
\text { snails/ } \\
\text { genus }\end{array}$ & $\begin{array}{l}\text { Sungai Papuyu and Kalumpang } \\
\text { Dalam Villages, Babirik District, } \\
\text { HSU Regency }\end{array}$ & $\begin{array}{l}\text { Echinostome cercariae were found in } \\
\text { snail Indoplanorbis and Echinostome } \\
\text { cercariae; Strigea cercariae; and } \\
\text { Obscuromicrocercous cercariae were } \\
\text { detected in snail Lymnaea. }\end{array}$ & [17] \\
\hline 2014 & - & $\begin{array}{l}\text { Sungai Papuyu and Kalumpang } \\
\text { Dalam Villages, Babirik District, } \\
\text { HSU Regency }\end{array}$ & $\begin{array}{l}\text { Echinostome cercariae were found in } \\
\text { snail Lymnaea and Indoplanorbis by } \\
\text { PCR method }\end{array}$ & [17] \\
\hline
\end{tabular}

$\mathrm{HSU}=$ Hulu Sungai Utara, $\mathrm{PCR}=$ Polymerase chain reaction

develop into sporocysts, redia, and cercariae. The latter escape from the snail and encyst in suitable aquatic plants [23]. Fasciolopsiasis occurs in humans when raw or undercooked aquatic vegetation is consumed.

Encysted cercariae develop into metacercariae, the infective form of the parasite for humans, in a variety of aquatic plants [24]. Several such plants that likely act as HP II hosts for fasciolopsiasis in the HSU are grown and commonly consumed by residents in areas where the parasite is endemic, especially lotus tubers and stems: Tatanding (Nymphaea alba and
Nymphaea lotus), susupan (Mimosa spp.), kangkung (Ipomea aquatica), genjer/patiul (Limnocharis flava), kalakai/pakis (Stenochlaena palustris), sulur, and tarati/palilak (Nymphaea) [22].

\section{Distribution Update in Indonesia}

F. buski surveillance activities began in 1985 in response to reports of children vomiting adult worms. The HSU Health Office conducted a massive surveillance program to ascertain infection prevalence and focus of intervention. Unfortunately, survey activities 
did not adequately define villages and district areas or attain program objectives [9]. The program did provide an overview of Fasciolopsis transmission in the HSU Regency from 1985 to 2001.

In 1985 and 1986, fasciolopsiasis prevalence increased rapidly from $20 \%$ to $27 \%$ and then gradually declined to $1 \%$ in 1997 and 1998. Surprisingly, disease prevalence was higher in 1998 and 1999 and then hovered between $2 \%$ and $4 \%$ in 2001 (Figure-3).

In 2002, surveillance and research efforts shifted focus to areas suspected of being centers for parasite transmission. Transmission occurred exclusively within the Babirik and Danau Panggang subdistricts [10,17]. Both areas are bound by rivers and tributaries that flow into the Nagara. These conditions provide the parasite with an aquatic environment for free-living forms and a habitat where snails, as the HP I, thrive. In addition, these two areas are mostly swampy and inundated by rising river levels. The distribution of F. buski from 2002 to 2018 is depicted in Figure-4.

From 2002 to 2018, fasciolopsiasis occurred locally in a few villages and three subdistricts in the HSU Regency (Figure-5). Babirik, Sungai Papuyu, and Telaga Mas villages exhibited the highest cumulative

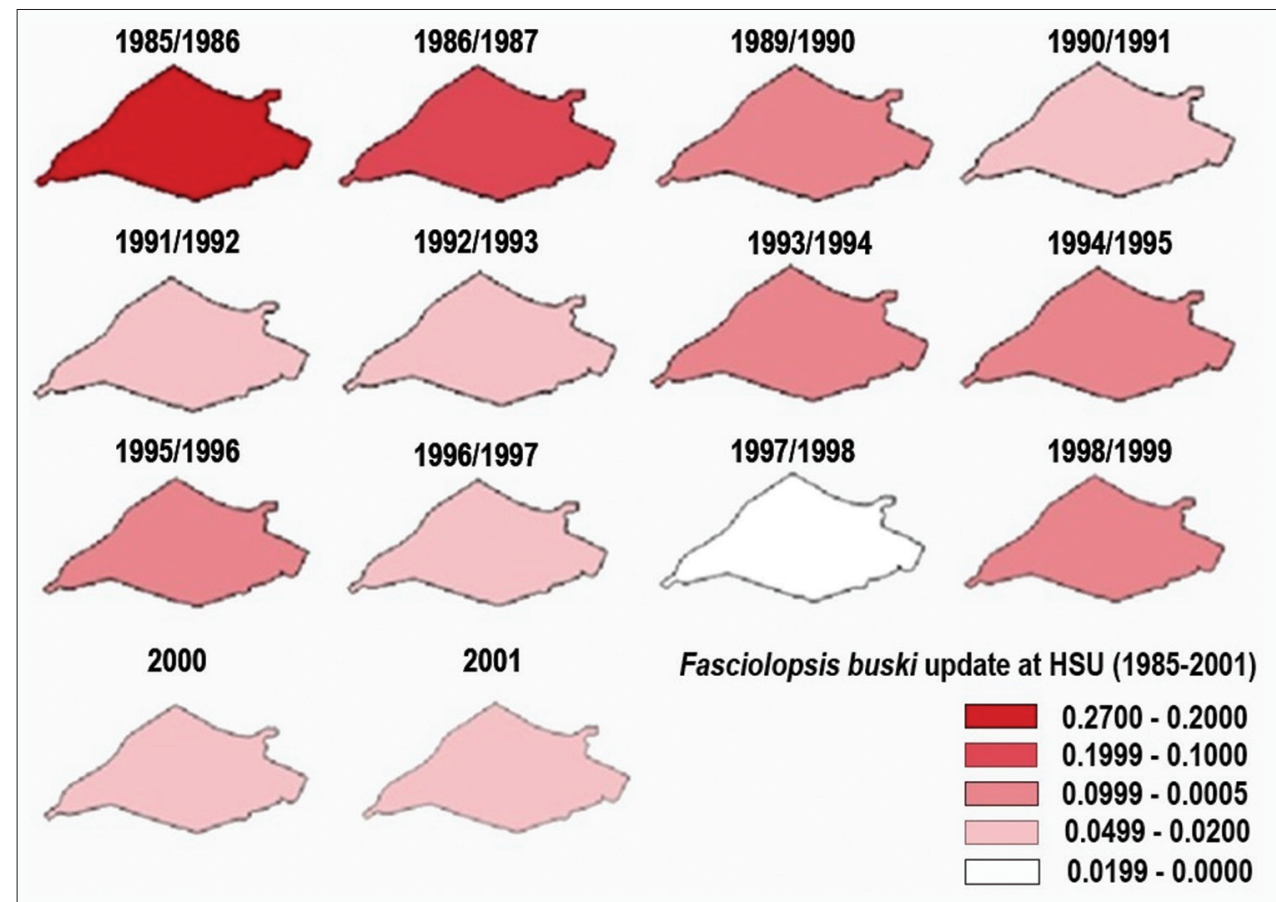

Figure-3: Fasciolopsis buski transmission updates 1985-2001 [Source: QGIS Nodebo 2.16.3].

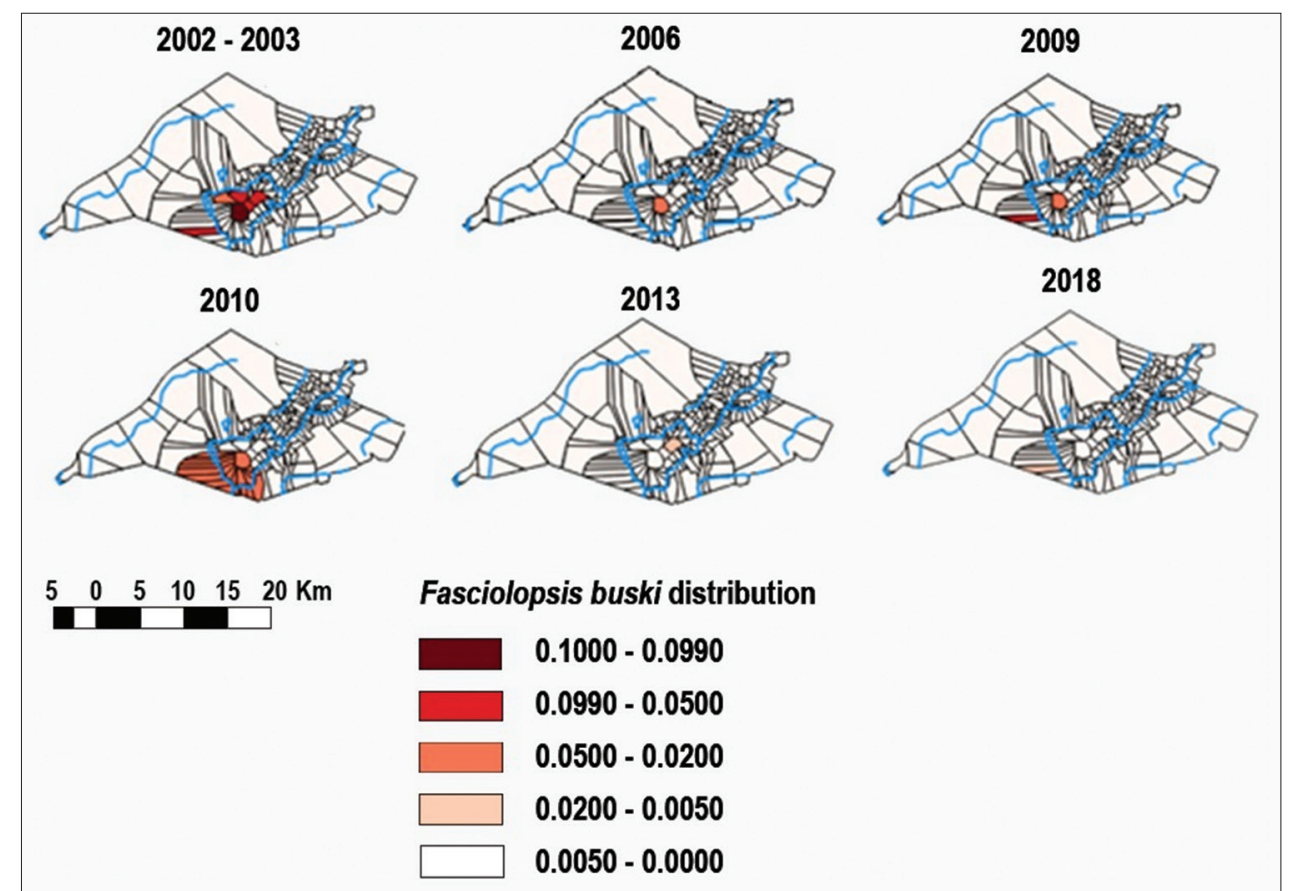

Figure-4: Distribution Fasciolopsis buski from 2002 to 2018 [Source: QGIS Nodebo 2.16.3]. 


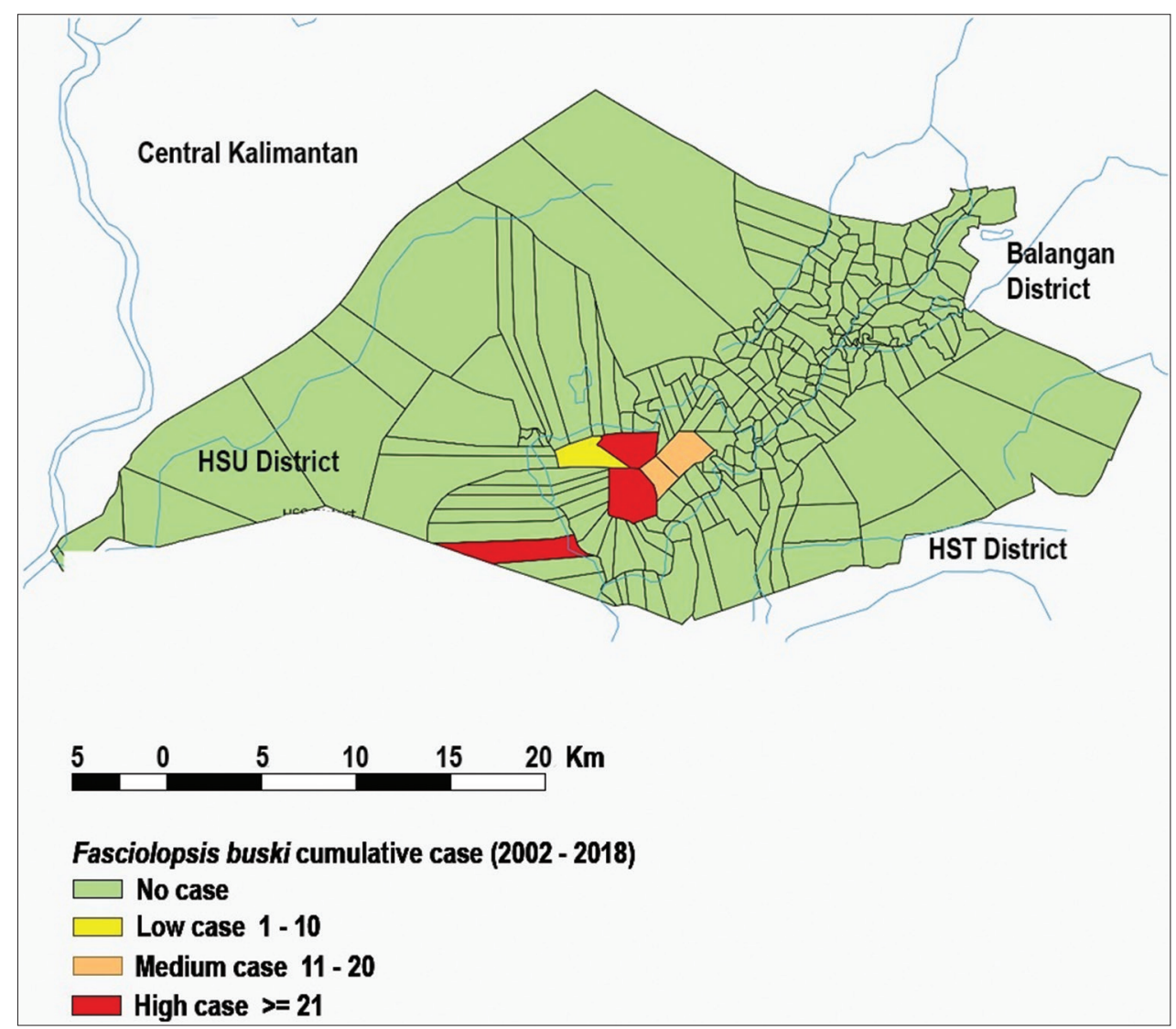

Figure-5: Cumulative cases of Fasciolopsis buski from 2002 to 2018 [Source: QGIS Nodebo 2.16.3].

numbers of cases, Padang Bangkal and Putat Atas villages showed moderate numbers, and Sarang Burung village reported few cases.

\section{Control Methods}

F. buski control in the HSU Regency involved treating patients with parasites with a single dose of praziquantel, $30 \mathrm{mg} / \mathrm{kg}$. This effort was a short-term attempt to reduce the prevalence of $F$. buski in residents of the regency. Further, long-term efforts were made to improve environmental sanitation through health promotion campaigns and intensive health education, particularly for elementary school students [9]. One method for education is the distribution of comic books in the Banjar language that contains information about the parasite, its transmission, clinical disease symptoms, diagnosis, and consequences of infection. Importantly, the books also include information for treatment and prevention of the disease [25]. This effort increased children's knowledge about $F$. buski infection by $14.8 \%$ and awareness of the importance of taking antiparasitic medication regularly by $11.2 \%$. In addition, children reduced their consumption of aquatic plants. The community as a whole began consuming less aquatic vegetation, such as lotus tubers and Caladium spp. (30.0\%), soup with raw fresh vegetables $(8.8 \%)$, and lotus seeds, talipuk (35.0\%) [25].

Further, a health promotion program with counseling was held in the HSU Regency using an Islamic religious lecture approach. This method was selected because Muslims constitute the majority of residents in F. buski endemic areas. The program was implemented in various Taklim groups at local mosques. Local religious leaders who had been trained by health officers delivered the lectures. This prevention approach was associated with the Islamic faith, as revealed in Al-Qur' an and Al Hadiths.

Many surveys were conducted to determine the effectiveness of promotional programs and to ascertain disease presence in the HSU Regency. Further, parasitological surveys were conducted to determine the dynamic prevalence of $F$. buski $[9,26]$. A separate investigation was focused on snails, reservoir hosts, and environmental assessments to identify factors that enhance infection and transmission of $F$. buski [17]. A survey and focus group discussions were used in some communities to assess the level of knowledge, attitude, and behavior [26].

\section{Discussion}

Geographically, the HSU Regency is located at $2^{\circ} 27^{\prime} 0^{\prime \prime} \mathrm{S}, 115^{\circ} 7^{\prime} 59.99^{\prime \prime} \mathrm{E}$. The regency is a lowland area with an elevation range of 0-7 $\mathrm{m}$ above sea level (masl) and a slope of 0-2\%. Rainfall is influenced by climatic and geographical factors and rotation/confluence of air currents. The HSU receives a great deal of precipitation. Much of the area can be submerged throughout the year; more than $570 \mathrm{~km}^{2}$ of the total area of $892.7 \mathrm{~km}^{2}$ is swampy. The majority of the land is underutilized. Snails and aquatic vegetation thrive under these conditions. 
Consumption of snails and raw aquatic plants, such as lotus shoots and tubers, water chestnuts, water caltrops, and lotus and water bamboo, consumption of untreated river or pond water, and frequent contact with livestock are all risk factors for $F$. buski infection [27,28]. An endemic district in the HSU Regency is associated with a community practice of consuming sweet lotus fruit and tubers (Nymphaea spp.), commonly referred to as "tanding" tubers. Exposure of children also occurs by ingesting raw water while swimming and playing after school $[9,13]$. The community consumes both lotus $(N . a l b a)$ and bird lotus ( $N$. lotus) [13]. Consumption of lotus tubers is a likely risk factor for $F$. buski infection in North India [21]. Water spinach (kangkung) is also a popular aquatic plant in the community and is linked with $F$. buski transmission in the HSU Regency [10] and Vietnam [29]. Consumption of metacercariae in aquatic plants was a primary factor in the outbreak in North India. However, consumption of snails also played a role [28]. Residents of the HSU Regency do not consume snails, but these mollusks are reservoir hosts that contribute significantly to the spread of the parasite. Indoplanorbis and Lymnaea spp. are likely cercariae carrier snail species [17].

Pigs and cows are reservoir hosts in the endemic area for F. buski in Bihar, India. Residents feed livestock lotus roots, which facilitates the spread of the parasite. In addition, high numbers of $F$. buski infections in Bihar were triggered by an appeal by a local nutritionist who suggested that snails could supply enough protein to support children's growth [30]. If not cooked properly, the risk of infection from snails harboring $F$. buski is high.

Treatment of $F$. buski in the HSU Regency differs slightly from the treatment used in Bihar, India, most notably with respect to dose. In the HSU Regency, treatment consisted of a single dose of praziquantel $30 \mathrm{mg} / \mathrm{kg}$ body weight. In Bihar, India, this drug is administered 3 times daily at a dose of $25 \mathrm{mg} / \mathrm{kg}$. The difference in dosage is most likely due to the region's high endemicity and prevalence of $F$. buski. The parasite was found in 55 of 118 samples examined (parasite rate $46.6 \%$ ). Adverse effects of praziquantel in Bihar included abdominal pain, nausea, and bloating followed by dizziness and headaches [30].

Due to limited data, surveillance efforts in the HSU district are necessary to obtain current data on prevalence and monitor F. buski elimination. Partnerships between the community and local governments must be strengthened to maximize prevention efforts.

\section{Conclusion}

Fasciolopsiasis has been found in Indonesia since 1982 and only in the HSU Regency, Indonesia. The number of detected cases declined every year. Continuous monitoring efforts by local health authorities are still needed. Prevention and controlling of fasciolopsiasis will require a restriction in the consumption of high-risk foods and elimination of open defecation, especially in ponded water frequented by the public. Cross-sector partnerships could be strengthened with countermeasures against parasite infection.

\section{Authors' Contributions}

MRR: Conception and designed the study. LI: Collected the literature and organized the database. DA: Designed a spatial analysis. AHW: Adding concepts and literature studies. All of the authors wrote the manuscript and critically oversaw substantial revisions and approved the final manuscript.

\section{Acknowledgments}

The authors would like to express their gratitude to the head of the Tanah Bumbu Health Research and Development Unit and the Indonesian Ministry of Health for their support in completing this manuscript.

\section{Competing Interests} interests.

The authors declare that they have no competing

\section{Publisher's Note}

Veterinary World remains neutral with regard to jurisdictional claims in published map and institutional affiliation.

\section{References}

1. Goddard, F.W. (1919) Fasciolopsis buski: A parasite of man as seen in Shaohing, China. J. Parasitol., 5(4): 141-163.

2. Hsieh, H.C. (1960) Studies on the epidemiology of Fasciolopsis buski in South Taiwan. Formos. Sci., 14(3): 95-120.

3. Cross, J.H. (1969) Fasciolopsiasis in Southeast Asia and the Far East: A review. Proceedings of the Fourth Southeast Asian Seminar on Parasitology and Tropical Medicine, Washington, DC. p177-199.

4. Manning, G.S. and Ratanarat, C. (1970) Fasciolopsis buski (Lankester, 1857) in Thailand. Am. J. Trop. Med. Hyg. 19(4): 613-619.

5. Gilman, R.H., Mondal, G., Maksud, M., Alam, K., Rutherford, E., Gilman, J.B. and Khan, M.U.(1982) Endemic focus of Fasciolopsis buski infection in Bangladesh. Am. J. Trop. Med. Hyg., 31(4): 796-802.

6. Ohi, T. (1924) On the Infection by Fasciolopsis buski (Lankester) among the Japanese. On the Infection's Route with the Human Body and the Pig. Tokyo Iji-Shinshi=Tokyo Medical News No. 2396.

7. Hadidjaja, P., Dahri, H.M., Roesin, R., Margono, S.S., Djalins, J. and Hanafiah, M. (1982) First autochthonous case of Fasciolopsis buski infection in Indonesia. Am. J. Trop. Med. Hyg., 31(5): 1065

8. Lu, X.T., Gu, Q.Y., Limpanont, Y., Song, L.G., Wu, Z.D., Okanurak, K. and Lv, Z.Y. (2018) Snail-borne parasitic diseases: An update on global epidemiological distribution, transmission interruption and control methods. Infect. Dis. Poverty, 7(1): 28.

9. Anorital, A., Dewi, R.M., Pancawati, O., Ompusunggu, S., Harijani, H. and Purnomo. (2005) Fasciolopsiasis prevalence study in Hulu Sungai Utara-South Kalimantan in 2002 and 2003. Media Health Res. Dev., 15(3): 1-7.

10. Anorital, A., Dewi, R.M., Purnomo, P., Ompusunggu, S. and Harijani, H. (2004) Epidemiological Study of Fasciolopsis buski in Hulu Sungai Utara, South Kalimantan, 2002-2003. Health Ecol. J., 4(1): 181-188. 
11. Annida, A. (2006) Fasciolopsiasis Prevention through Administration of Drugs 2 (Two) Times a Year in Hulu Sungai District. Research Report, Tanah Bumbu, Indonesia.

12. Waris, L. (2009) Distribution of Digestive Parasites in Communities with Different Ecosystems in South Kalimantan Province. Research Report, Tanah Bumbu, Indonesia.

13. Muhammad, M., Rifqoh, R., and Sara, I.R. (2016) Consumption of lotus fruit (Nymphaea sp) as a determinant of the occurrence of Fasciolopsis buski in children. Med. Lab. Technol. J., 2(1): 1-6.

14. Khairudin, K., Yudhastuti, R. and Lusno, M.F.D. (2013) The affecting factors of fasciolopsiasis in the elementary student in endemic area. Makara J. Health Res., 16(2): 84-88.

15. A. Annida. (2012) Comprehensive epidemiological study of Fasciolopsiasis and its mapping in HSU District. Research Report, Tanah Bumbu, Indonesia.

16. M.I. Satrio, P. Puspitawati, and M. Arsyad. (2018) Fasciolopsis buski identification on Elementary School 'Sungai Papuyu' Chidren stools in Babirik Subdistrict Hulu Sungai Utara Regency 2018. Research Report, Banjarmasin, Indonesia.

17. Hairani, B., Annida, A., Hidayat, S. and Fakhrizal, D. (2016) Identification of Fasciolopsis buski Cercaria by PCR for confirmation of intermediate host in Hulu Sungai Utara district, South Kalimantan, Indonesia. BALABA, 12(1): 7-14.

18. CDC. (2012) Fascilopsiasis (Trematode Fasciolopsis buski). Global Health, Division of Parasitic Diseases and Malaria, Atlanta.

19. Nakagawa, K. (1922) The development of Fasciolopsis buski Lankester. J. Parasitol., 8(4): 161-166.

20. Hsu, P.J. (1964) A survey of fasciolopsiasis of pigs in Kwangtung province. Acta Vet. Zootech. Sin., 7(2): 143-150.

21. Rajendran,C.A., Satbigea, S. andKumar,D.(2019) Review on zoonotic parasitic diseases of northeast India-epidemiology and clinical features. Int. J. Curr. Microbiol. Appl. Sci., 8(2): 2019.

22. Anorital, A. and Annida, A. (2011) Intermediary hospes and reservoir hospes Fasciolopsis buski in Indonesia epidemiological study of $F$. buski in Hulu Sungai Utara district, South Kalimantan, 2002 and 2010. Vektora, 3(2): 110-119.

23. Mahajan, R.K., Duggal, S., Biswas, N., Duggal, N. and Hans, C. (2010) A finding of live Fasciolopsis buski in an ileostomy opening. J. Infect. Dev. Ctries., 4(6): 401-403.

24. Mohanty, I., Narasimham, M.V., Sahu, S., Panda, P. and Parida, B. (2012) Live Fasciolopsis buski vomited out by a boy. Ann. Trop. Med. Public Health, 5(4): 403.

25. Anorital, A., Kasnodiharjo, K., Dewi R.M. and Ompusunggu S. (2008) Improving knowledge and behavior aspects of elementary school/madrasah ibtidaiyah children through buski comics in three enemis Fasciolopsis buski villages in Hulu Sungai Utara District, 2003. Media Health Res. Dev., 18(1): 8-15.

26. Anorital, A. and Dewi, R.M. (2009) Increasing public knowledge through a religious approach in the endemic area of Fasciolopsis buski in Hulu Sungai Utara regency. Indonesian Infect. Dis. J., 1(1): 1-9.

27. Sah, R., Calatri, M. and Toledo, R. (2019) An autochthonous human case of fasciolopsiasis in Nepal. Korean $J$. Parasitol., 57(3): 295-298.

28. Saurabh, K. and Ranjan, S. (2017) Fasciolopsiasis in children: Clinical, sociodemographic profile and outcome. Indian J. Med. Microbiol., 35(4): 6-11.

29. Fiamma, M., Longoni, S.S., Ngo, T.M.C., Le Phan, M.T., Santona, A., Ton Nu, P.A. and Paglietti, B. (2015) Case report Fasciolopsis buski infection in a Vietnamese pregnant woman with systemic lupus erythematosus. $J$. Infect. Dev. Ctries., 9(6): 670-673.

30. Achra, A., Prakash, P. and Shankar, R. (2015) Fasciolopsiasis: Endemic focus of a neglected parasitic disease in Bihar. Indian J. Med. Microbiol., 33(3): 364-368. 